\title{
The effects of sex, age and cigarette smoking on micronucleus and degenerative nuclear alteration frequencies in human buccal cells of healthy Bosnian subjects
}

\begin{abstract}
Hilada Nefic ${ }^{*}$, Jasmin Musanovic², Kemajl Kurteshi ${ }^{3}$ Enida Prutina1 ${ }^{1}$ Elvira Turcalo
'Department of Biology, Faculty of Science, University of Sarajevo, Bosnia and Herzegovina. ${ }^{2}$ Department for Biology and Human Genetics, Medical Faculty, University of Sarajevo, Bosnia and Herzegovina. ${ }^{3}$ Department of Biology, Faculty of Science, University of Prishtina, Prishtina, Kosovo.
\end{abstract}

\begin{abstract}
Introduction: This study was performed to establish a baseline value of micronucleus frequency in buccal cells and to estimate the impact of the most common factors (sex and age, and smoking) on micronucleus and degenerative nuclear alteration frequencies in the sample of healthy Bosnian subjects.
\end{abstract}

Methods: The Buccal Micronucleus Cytome (BMCyt) assay, based on scoring not only micronucleus frequency but also other genome damage markers, dead or degenerated cells, provides a measure of cytotoxic and genotoxic effects.

Results: Our results showed the baseline buccal micronucleus frequency was $0.135 \%$ or $1.35 \%$, as well as positive correlations between micronucleus frequencies and formations of degenerative nuclear alterations (nuclear buds, karyolytic and karyorrhectic cells). The number of micronuclei in buccal cells was significantly higher in females than in males. There was positive association between the age and frequency of analysed cytogenetic biomarkers. Buccal cell micronuclei and degenerative nuclear alternations were more frequent among cigarette smokers than non-smokers and significantly higher in female smokers than in male smokers. Cytogenetic damages showed significantly positive correlation between intensity of smoking and the number of nuclear alterations. The years of smoking had a significant influence not only on the number of nuclear alterations but also in micronuclei and nuclear buds in buccal cells.

Conclusions: The sex influences the number of micronuclei in human buccal cells. The ageing increased the number of micronuclei and other biomarkers of DNA damage. The cigarette smoking significantly increases the frequencies of micronuclei and nuclear buds, pyknotic, karyolytic and karyorrhectic cells.

Keywords: Micronuclei, Degenerative nuclear alterations, Buccal cells, Sex, Age, Smoking

${ }^{*}$ Corresponding author: Hilada Nefic Department of Biology, Faculty of Science, University of Sarajevo, Bosnia and Herzegovina

Phone: +38733723717; Fax: +38733649359

E-mail: hnefic@gmail.com

Submitted 8 June 2013 / Accepted 1 October 2013

\section{INTRODUCTION}

The Buccal Micronucleus Cytome (BMCyt) assay is a method for studying the effects of lifestyle factors, nutrition, genotoxin exposure and genotype on DNA damage, chromosomal aberrations and 
malsegregation, cell death and regenerative potential of human buccal cells. Demographic factors, sex and age, also affect micronucleus (MN) frequency in buccal cells. Epithelial cells do not need to be stimulated and micronuclei $(\mathrm{MNi})$ in exfoliated cells reflect genotoxic events that occurred in the dividing basal cell layer 1-3 weeks earlier. This method is minimally invasive and repeated sampling is acceptable $(1,2)$.

The human micronucleus assay in exfoliated buccal cells $\left(\mathrm{HUMN}_{\mathrm{XI}}\right)$ project, established in 2009 , is an international collaborative project for studying DNA damage in human populations. This project was aimed to standardize micronucleus assay in oral buccal cells (2).

Baseline frequencies for micronucleated cells (MNC) in the BMCyt are usually within the $0.5-2.5 \mathrm{MNi}$ per 1,000 cells range (3). The factors potentially affecting baseline buccal MN frequency are methodological, exposure, diet, lifestyle and demographic (age and sex). The age, sex and smoking habit were the most commonly studied factors. Piyathilake et al (4) reported that frequencies of micronucleated cells are higher in females after adjusting for age and smoking habit, whereas in a Brazilian study (5) the number of micronuclei was significantly higher in males. Higher frequency of micronuclei was ob- served in cells collected from female smokers than male smokers but sex and age did not influence micronuclei frequency of non-smokers (6). Nersesyan et al (7) observed a weak association between the age of the participants and the overall frequency of MNC cells. Some studies showed an increase with age $(4,8)$ and in another a decrease with age (9), but in some studies no effect was detected $(5,10$ 11). Cigarette smoking is one of the factors that may influence the number of MNi in buccal cells $(4,12)$. Smoking is also reported to increase the MN frequency in human lymphocytes $(13,14)$.

The BMCyt assay has been used to measure biomarkers of DNA damage (micronuclei and nuclear buds, NBUDs), cytokinetic defects (binucleated cells) and proliferative potential (basal cell frequency) and cell death (condensed chromatin; karyorrhectic, KHC; pyknotic, PYK and karyolitic, KYL cells). In the BMCyt assay, buccal cells are classified into categories that distinguish between 'normal' cells and cells that are 'damaged' on the basis of cytological and nuclear features (Figure 1).

Besides, the BMCyt assay can detect an increase in $\mathrm{MN}$ frequency in exfoliated buccal cells after exposure to different genotoxic factors (e.g. chemicals, radiation, lifestyle factors); this assay also has the potential to identify inherited genomic instability such
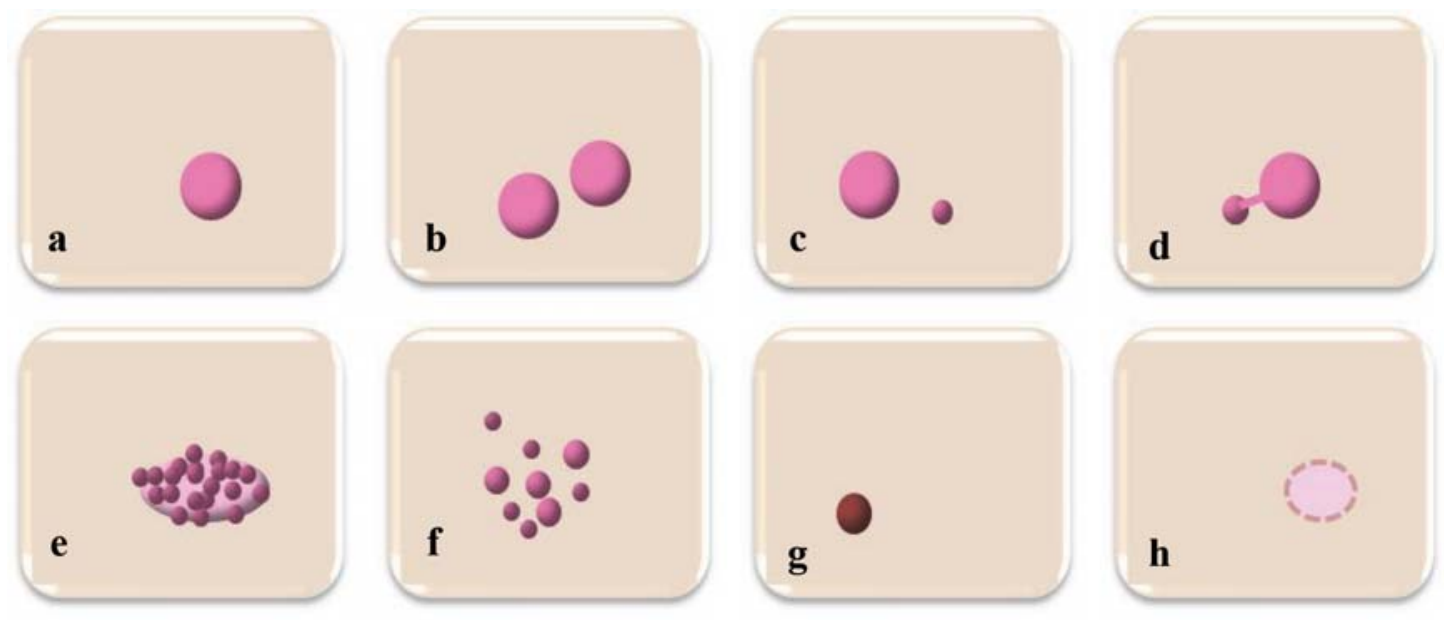

FGURE 1 Schematic diagram of different types of buccal cells and the possible mechanisms for their origin; (a) normal differentiated cell (normal genome); (b) binucleated cell (cytokinesis defect); (c); micronucleated cell (chromosome breakage or loss); (d) nuclear bud (gene amplification); (e) condensed chromatin (apoptotic cell death); (f) karyorrhexis (apoptotic cell death); (g) pyknosis (apoptotic cell death); (h) karyolysis (necrotic cell death). 
as Bloom's syndrome. The biomarkers measured in this assay have been associated with normal ageing and premature ageing in clinical outcomes such as Down's syndrome and Alzheimer's disease. The buccal MN assay is used as a biomarker of cancer risk.

The aim of the present study was to evaluate the baseline micronucleus frequency in human buccal cells in the sample of healthy Bosnian subjects. In addition to counting micronuclei, degenerative nuclear alterations indicative of apoptosis (karyorrhectic, pyknotic and karyolytic cells) were also investigated in the BMCyt assay.

We hypothesized that sex and age of participants affect $\mathrm{MN}$ and other biomarker frequencies in human buccal cells. Smoking habit was also taken into account.

\section{METHODS}

Exfoliated cells of the human buccal mucosa for the buccal micronucleus cytome (BMCyt) assay were collected from 120 healthy females and males, mostly younger subjects from Central Bosnia and Herzegovina. Participants were aged between 19 and 50 years (with mean age of $25.33 \pm 4.90$ years). Signed informed consent was obtained from each individual. Information on date of birth, sex and smoking status and history (the number of cigarettes smoked per day and duration of smoking in year) was obtained by the questionnaire.

In this study, the BMCyt assay was used for studying biomarkers of DNA damage, cytokinetic defects and cell death. Individuals rinsed their mouth with water and wooden tongue depressor was used to col- lect cells from the inner wall of the cheek. The slides were prepared by direct smearing of buccal cells to cleaned microscope slide. The smears were air dried and slides were stained by $2 \%$ acetorcein (Gurr Orcein, BDH Chemicals Ltd., Poole, England). Stained slides were used for microscopic analysis.

Exfoliated buccal cells were analysed under a total magnification of x1000 using a Jenaval microscope. Only cells that were not clumped or overlapped and that contained intact nuclei were included in the analysis of MNi. The frequency of micronuclei and degenerative nuclear alterations (nuclear buds, pyknotic, karyolytic and karyorrhectic cells) in differentiated human buccal cells were recorded. Applied criteria for identifying and scoring cell types in the BMCyt assay, based on morphological features of cells, were described by Tolbert et al. (1), Sarto et al. (15) and Thomas et al. (16). According to these criteria, normal differentiated cell has a smaller nuclearcytoplasmic ratio relative to basal cell, more angular and flatter than basal cells, uniformly stained round nucleus. The micronucleated cell contains both the main nucleus and micronucleus and micronuclei are round or oval with similar stain intensity as the main nucleus. The micronuclei usually have $1 / 3-1 / 16 \mathrm{di}-$ ameter of the main nucleus located in cellular cytoplasm. Most cells with $\mathrm{MNi}$ contain only one $\mathrm{MN}$ but it is possible to find cells with two or more $\mathrm{MNi}$. The cells with nuclear bud on the main nucleus have a sharp constriction forming a bud. The bud is attached to the main nucleus and has a similar staining intensity as the main nucleus. Its diameter can be a quarter to half of nuclear diameter. The karyorrhectic cells have nucleus with extensive aggregated

TABLE1 Selected characteristics of the studied subjects (mean \pm SD per subject).

\begin{tabular}{|c|c|c|c|c|c|c|c|c|}
\hline & \multicolumn{2}{|c|}{ Subjects } & \multirow[t]{2}{*}{ Mean age at test (yrs) } & \multicolumn{2}{|c|}{ Current smokers } & \multirow[t]{2}{*}{ Cigarettes per day } & \multirow[t]{2}{*}{ Years smoking } & \multirow[t]{2}{*}{ Period of sampling } \\
\hline & $\mathrm{N}$ & $\%$ & & $\mathrm{~N}$ & $\%$ & & & \\
\hline Total & 120 & 100 & $25.33 \pm 4.90$ & 60 & 100 & $17.62 \pm 9.26$ & $6.97 \pm 5.78$ & 2009-2012 \\
\hline Females & 67 & 55.8 & $25.54 \pm 4.76$ & & & & & \\
\hline Smokers & 37 & 30.8 & $25.76 \pm 6.02$ & 37 & 61.7 & $15.19 \pm 8.69$ & $6.30 \pm 4.95$ & \\
\hline Non-smokers & 30 & 25.0 & $25.27 \pm 2.53$ & & & & & \\
\hline Males & 53 & 44.2 & $25.06 \pm 5.10$ & & & & & \\
\hline Smokers & 23 & 19.2 & $25.39 \pm 6.49$ & 23 & 38.3 & $21.52+8.97^{*}$ & $8.04 \pm 6.89$ & \\
\hline Non-smokers & 30 & 25.0 & $24.80 \pm 3.83$ & & & & & \\
\hline
\end{tabular}

SD, standard deviation. Significance was accepted at $P<0.05$. Significant results in bold. Sex: ${ }^{*} P<0.001$. 
chromatin, while nuclear fragmentation may be evident. The pyknotic cell has small shrunken nucleus. The nucleus is uniformly and intensely stained and its diameter is $1 / 3-2 / 3$ diameter of normal nucleus. The karyolytic cells are cells in which the nucleus is completely depleted of DNA. The nucleus is apparent as a ghost-like image that has no Orcein staining. First, we determined the number of karyorrhectic, pyknotic and karyolitic cells per 1,000 differentiated cells for score slides in the BMCyt assay. The number of DNA damage biomarkers ( $\mathrm{MNi}$ and NBUDs) is scored in 1,000 differentiated cells, because of the very low number of basal cells. Data were expressed as the mean \pm standard deviation (SD) of the means. The frequencies of various cell types in the assay are represented as the number of cells in a 1,000 cells.

In our study, sex, age and lifestyle-related variable of smoking habits (the number of cigarettes smoked per day and duration of smoking in a year), that could affect the number of studied biomarkers, was considered. The subjects were divided into groups, according to their sex (females and males). Additionally, females and males were divided into subgroups with regard to smoking habit (smokers and non-smokers), based on their responses to the questionnaire. Smoking habit was ranked as smoker or non-smoker. Individuals who had consumed four or more cigarettes per day for at least two years were considered to be smokers. These groups (smokers and non-smokers) were divided into subgroup with regard to sex (Table 1 ).

\section{Statistical analysis}

The presence of statistically significant differences in the occurrence of damaged cells between studied groups and subgroups is tested with a Student's ttest (comparing two means). Also, to evaluate the association between age or smoking and each biomarker, Pearson's method ( $r$ ) was performed. The value of $\mathrm{P}<0.05$ was considered statistically significant. All statistical analyses were carried out using Microsoft Excel 2010 (Microsoft Corporation) and the Windows Kwikstat Winks SDA 7.0.2 statistical software package (Texa Soft Cedar Hill, Texas).

\section{RESULTS}

The sample included 120 subjects, 67 females $(55.8 \%)$ and 53 males (44.2\%) with ages ranging from 19 to 50 years (mean \pm SD: $25.33 \pm 4.90$ ). The mean ages of the females and males were 25.06 \pm 5.10 (ages ranging from 19 to 50 years) and 25.54 \pm 4.76 years (ages ranging from 20 to 50 years), respectively. Table 2 presents the effects of sex and smoking on buccal cell micronucleus and nuclear alteration frequencies in healthy persons. Student's t-test showed there wasn't significant difference

TABLE2. Effects of sex and smoking on buccal cell MN and nuclear alteration frequencies in healthy persons (mean \pm SD per subject).

\begin{tabular}{|c|c|c|c|c|c|c|c|c|c|}
\hline Samples & $\begin{array}{l}\text { Subjects } \\
\text { (N) }\end{array}$ & $\begin{array}{l}\text { Mean age } \\
\text { at test (yrs) }\end{array}$ & $\begin{array}{c}\text { Cigarettes } \\
\text { per day }\end{array}$ & $\begin{array}{c}\text { Years } \\
\text { smoking }\end{array}$ & PYK cell & KYL cell & $\mathrm{KHC}$ cell & NBUD & $\mathrm{MN}$ \\
\hline Total & 120 & $25.33 \pm 4.90$ & $17.62 \pm 9.26$ & $6.97 \pm 5.78$ & $2.08 \pm 2.9$ & $1.93 \pm 1.54$ & $5.72 \pm 3.53$ & $0.02 \pm 0.13$ & $1.35 \pm 1.15$ \\
\hline Females & 67 & $25.54 \pm 4.76$ & $15.19 \pm 8.69$ & $6.30 \pm 4.95$ & $1.66 \pm 1.86$ & $1.72 \pm 1.20$ & $5.22 \pm 2.94$ & $0.00 \pm 0.00$ & $1.57 \pm 1.34^{*}$ \\
\hline Males & 53 & $25.06 \pm 5.10$ & $21.52 \pm 8.97^{\star *}$ & $8.04 \pm 6.89$ & $2.57 \pm 3.74$ & $2.18 \pm 1.85$ & $6.29 \pm 4.09$ & $0.04 \pm 0.19$ & $1.08 \pm 0.78$ \\
\hline Females & 67 & $25.54 \pm 4.76$ & $15.19 \pm 8.69$ & $6.30 \pm 4.95$ & $1.66 \pm 1.86$ & $1.72 \pm 1.20$ & $5.22 \pm 2.94$ & $0.00 \pm 0.00$ & $1.57 \pm 1.34$ \\
\hline Smokers & 37 & $25.76 \pm 6.02$ & $15.19 \pm 8.69$ & $6.30 \pm 4.95$ & $2.06 \pm 2.22$ & $2.06 \pm 1.34^{b}$ & $6.35 \pm 3.41^{c}$ & $0.00 \pm 0.00$ & $2.05 \pm 1.53^{c}$ \\
\hline Non-smokers & 30 & $25.27 \pm 2.53$ & & & $1.20 \pm 1.26$ & $1.33 \pm 0.90$ & $3.93 \pm 1.58$ & $0.00 \pm 0.00$ & $0.97 \pm 0.72$ \\
\hline Males & 53 & $25.06 \pm 5.10$ & $21.52 \pm 8.97$ & $8.04 \pm 6.89$ & $2.57 \pm 3.74$ & $2.18 \pm 1.85$ & $6.29 \pm 4.09$ & $0.04 \pm 0.19$ & $1.08 \pm 0.78$ \\
\hline Smokers & 23 & $25.39 \pm 6.49$ & $21.52 \pm 8.97$ & $8.04 \pm 6.89$ & $3.54 \pm 5.24$ & $2.85 \pm 2.34^{a}$ & $8.23 \pm 5.07^{b}$ & $0.08 \pm 0.28$ & $1.30 \pm 0.88^{a}$ \\
\hline Non-smokers & 30 & $24.80 \pm 3.83$ & & & $1.73 \pm 1.33$ & $1.60 \pm 1.06$ & $4.60 \pm 1.92$ & $0.00 \pm 0.00$ & $0.90 \pm 0.70$ \\
\hline
\end{tabular}

Results shown are 'per 1,000 cells'. SD, standard deviation. Significance was accepted at $P<0.05$. Significant results in bold. Sex: ${ }^{*} P<0.05 ;{ }^{* *} \mathrm{P}<0.001$. Smoking: a $<0.05$; ${ }^{\mathrm{b} P}<0.01 ;{ }^{\mathrm{c} P}<0.001$. 
TABLE 3. Comparison of cytogenetic biomarker frequencies by stratification of sex and smoking status. All values are given as mean \pm SD per subject.

\begin{tabular}{|c|c|c|c|c|c|c|c|c|c|}
\hline Samples & $\begin{array}{l}\text { Subjects } \\
\text { (N) }\end{array}$ & $\begin{array}{l}\text { Mean age } \\
\text { at test (y) }\end{array}$ & $\begin{array}{l}\text { Cigarettes } \\
\text { per day }\end{array}$ & $\begin{array}{l}\text { Smoking } \\
\text { duration (y) }\end{array}$ & PYK cell & KYL cell & KHC cell & NBUD & MN \\
\hline Total & 120 & $25.33 \pm 4.90$ & $17.62 \pm 9.26$ & $6.97 \pm 5.78$ & $2.08 \pm 2.9$ & $1.93 \pm 1.54$ & $5.72 \pm 3.53$ & $0.02 \pm 0.13$ & $1.35 \pm 1.15$ \\
\hline Smoker & 60 & $25.62 \pm 6.15$ & $17.62 \pm 9.26$ & $6.97 \pm 5.78$ & $2.70 \pm 3.83^{a}$ & $240 \pm 185^{b}$ & $7.17 \pm 4.24^{b}$ & $0.03 \pm 0.18$ & $178 \pm 1.35^{b}$ \\
\hline Non-smoker & 60 & $25.03 \pm 3.23$ & & & $1.47 \pm 1.31$ & $1.47 \pm 0.97$ & $4.27 \pm 1.76$ & $0.00 \pm 0.00$ & $0.93 \pm 0.71$ \\
\hline Smoker & 60 & $25.62 \pm 6.15$ & $17.62 \pm 9.26$ & $6.97 \pm 5.78$ & $2.70 \pm 3.83$ & $2.40 \pm 1.85$ & $7.17 \pm 4.24$ & $0.03 \pm 0.18$ & $1.78 \pm 1.35$ \\
\hline Females & 37 & $25.76 \pm 6.02$ & $15.19 \pm 8.69$ & $6.30 \pm 4.95$ & $2.06 \pm 2.22$ & $2.06 \pm 1.34$ & $6.35 \pm 3.41$ & $0.00 \pm 0.00$ & $2.05 \pm 1.53^{*}$ \\
\hline Males & 23 & $25.39 \pm 6.49$ & $21.52+8.97$ ** & $8.04 \pm 6.89$ & $3.54 \pm 5.24$ & $2.85 \pm 2.34$ & $8.23 \pm 5.07$ & $0.08 \pm 0.28$ & $1.30 \pm 0.88$ \\
\hline Non-smoker & 60 & $25.03 \pm 3.23$ & & & $1.47 \pm 1.31$ & $1.47 \pm 0.97$ & $4.27 \pm 1.76$ & $0.00 \pm 0.00$ & $0.93 \pm 0.71$ \\
\hline Females & 30 & $25.27 \pm 2.53$ & & & $1.20 \pm 1.26$ & $1.33 \pm 0.90$ & $3.93 \pm 1.58$ & $0.00 \pm 0.00$ & $0.97 \pm 0.72$ \\
\hline Males & 30 & $24.80 \pm 3.83$ & & & $1.73 \pm 1.33$ & $1.60 \pm 1.06$ & $4.60 \pm 1.92$ & $0.00 \pm 0.00$ & $0.90 \pm 0.70$ \\
\hline
\end{tabular}

Results shown are 'per 1,000 cells'. SD, standard deviation. Significance was accepted at $P \leq 0.05$. Statistically significant values are indicated in bold. Sex: ${ }^{*} P<0.05 ;{ }^{* *} P<0.001$. Smoking: ${ }^{\text {aP }}<0.05$; ${ }^{\text {b }}<0.001$.

between males and females in relation to age $(\mathrm{t}=$ 0.53; $\mathrm{p}=0.599$ ), which is important, given the fact that the influence of sex and smoking on the occurrence of cytogenetic markers is observed. The males consumed statistically significant higher number of cigarettes per day than females $(t=3.91 ; \mathrm{p} \leq 0.001)$. The mean baseline MN frequency in the examined sample of individuals was $1.35 \pm 1.15$ per subject (per 1,000 cells), $0.135 \%$ or $1.35 \%$. We didn't observe $\mathrm{MNi}$ in buccal cells of 23 subjects. Most MNC cells contain only one MN $(97.5 \%$ of micronucleated cells) but it is possible to find cells with two or even more $\mathrm{MNi}$ (range 1 - $6 \mathrm{MNi}$ per thousand buccal cells). Therefore, the frequency of MNC cells and the frequency of $\mathrm{MNi}$ per 1,000 cells were almost identical (Figure 2). We didn't observe degenerative nuclear alterations (Figure 3) in differentiated cells of only three subjects, and nuclear alterations ranging between 1 and 35 per thousand buccal cells.

The data obtained by Student's t-test showed that the number of $\mathrm{MNi}$ was higher in females (mean \pm SD: $1.57 \pm 1.34$ ), as compared with males (mean \pm SD: $1.08 \pm 0.78)$, the difference being statistically significant $(t=2.5 ; \mathrm{p}=0.014)$. The ratio between females and males was 1.45 . On the other side, the number of cells with NBUDs was higher in males than in females, but the difference was statistically non-significant. The number of degenerated cells resulting from karyorrhesis (KHC cells), karyolysis
(KYL cells) and nucleus fragmentation (PYC cells) was also increased in males, but these differences were not statistically significant. The female or male smokers had statistically significant more $\mathrm{MNi}$ (females: $\mathrm{t}=3.81 ; \mathrm{p} \leq 0.001$ and males: $\mathrm{t}=2.07 ; \mathrm{p}=$ 0.043), KYL (females: $\mathrm{t}=2.66 ; \mathrm{p}=0.01$ and males: $\mathrm{t}=2.38 ; \mathrm{p}=0.024$ ) and KHC cells (females: $\mathrm{t}=$ 3.84; $\mathrm{p} \leq 0.001$ and males: $\mathrm{t}=3.26 ; \mathrm{p}=0.003)$ than female or male non-smokers.

To determine the correlation between age and cytogenetic biomarkers, Pearson's method was per-

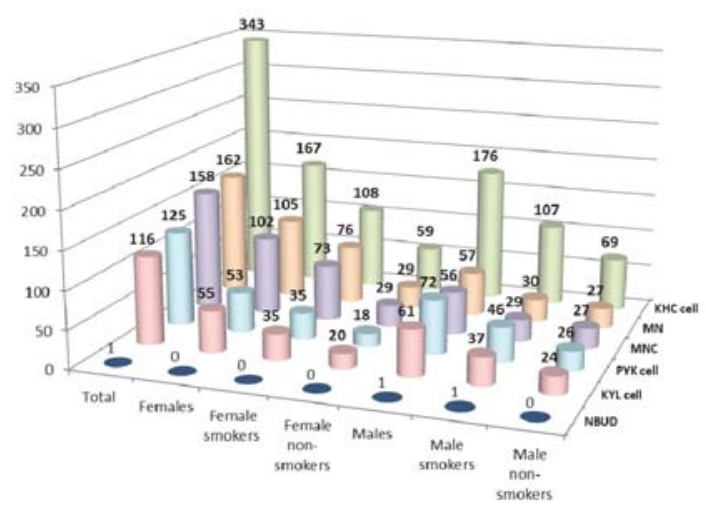

FGURE2. The frequencies of micronuclei and other nuclear alterations in exfoliated buccal cells of studied subjects. Average cells scored per subject (per 1,000 cells). PYK, pyknotic; KYL, karyolytic; KHC, karyorrhectic; NBUD, nuclear bud; MNC, micronucleated cells; MN, micronucleus. 

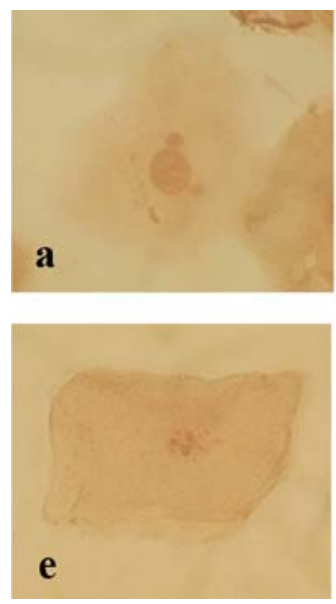
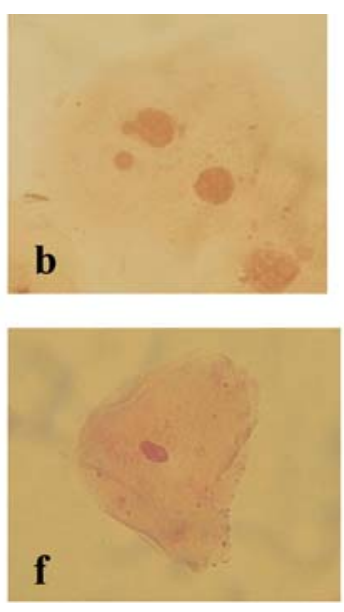
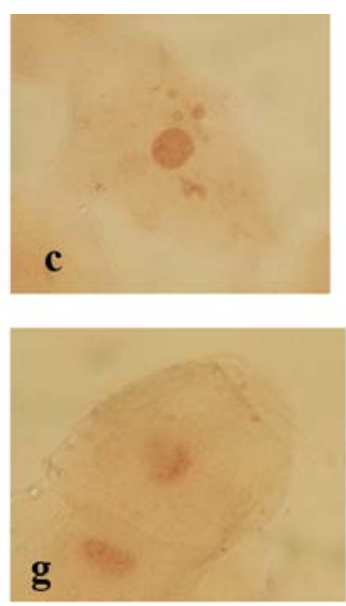
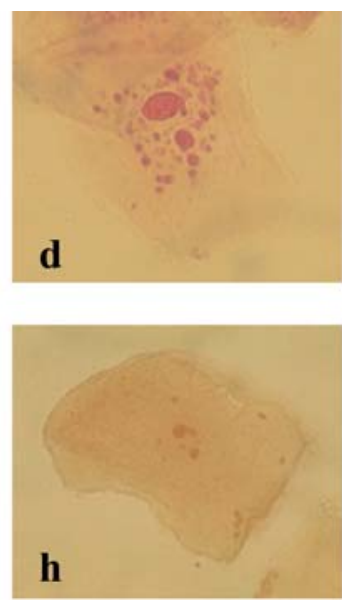

RGURE 3. Photomicrographs of exfoliated buccal cells stained using acetorcein in the BMCyt assay; (a) differentiated cell with two micronuclei; (b) cell with a micronucleus and nuclear bud; (c) and (d) cells with more micronuclei; (e) karyorrhectic cell; (f) pycnotic cell; (g) karyolytic cell; (h) fragmented nucleus. All photos were taken at 1,000x magnification.

formed. In the sample including both males and females during this study, we found significantly positive correlation between ageing and the number of MNi ( $\mathrm{r}=0.4300 ; \mathrm{p}<0.001)$, NBUDs $(\mathrm{r}=$ $0.2959 ; \mathrm{p}=0.022), \mathrm{KHC}(\mathrm{r}=0.3109 ; \mathrm{p}=0.016)$ and KYL cells $(\mathrm{r}=0.3623 ; \mathrm{p}=0.004)$. These results showed that micronucleus and other cytogenetic markers frequencies tended to be greater in older subjects than in younger subjects.

Pearson's analysis was applied in order to investigate the association between micronucleus formations in human buccal cells and the number of degenerative nuclear alterations. We found significantly positive correlation between the number of MNi in cells and the number of degenerative nuclear alterations in differentiated buccal cells; for NBUDs: $r=0.3644$; $\mathrm{p}=0.004$, KHC cells: $\mathrm{r}=0.2905 ; \mathrm{p}=0.024$ and for KYL cells: $r=0.3076 ; \mathrm{p}=0.017$.

Sample included 60 smokers, 37 females (61.67\%) and 23 males (38.33\%). The average age of smokers was $25.62 \pm 6.15$ and non-smokers $25.03 \pm 3.23$ (Table 3). This difference was not statistically significant and we can study effects of sex on the number of examined biomarkers.

The frequency of $\mathrm{MNi}$ of oral epithelial cells was twice as high in smokers as in non-smokers; recorded $\mathrm{MNi}$ frequency values were $1.78 \pm 1.35$ and 0.93 \pm 0.71 , respectively.
The cells with anomalies other than $\mathrm{MNi}$, such as PYK, KYL, KHC cells, are significantly increased in smokers. In Student's t-test, the smokers had statistically significant increased number of $\mathrm{MNi}(\mathrm{t}=$ 4.32; $\mathrm{p} \leq 0.001)$, PYK $(\mathrm{t}=2.35 ; \mathrm{p}=0.021)$, KYL $(\mathrm{t}=3.45 ; \mathrm{p} \leq 0.001)$ and KHC cells $(\mathrm{t}=4.99 ; \mathrm{p}$ $\leq 0.001)$ than non-smokers. Regarding the sex of smokers, females had significantly higher number of $\mathrm{MNi}$ in exfoliated buccal cells $(\mathrm{t}=2.25 ; \mathrm{p}=0.028)$ when compared with males, although males smoke significantly more cigarettes per day $(\mathrm{t}=2.71 ; \mathrm{p}$ $=0.009)$ than females. The ratio of $\mathrm{MNi}$ between females and males was 1.52. The males had higher number of other biomarkers examined (PYK, KYL and KHC cells, also NBUDs) when compared with females, however these differences were not statistically significant. In the group of non-smokers, there is not statistically significant difference in the number of observed cytogenetic markers between males and females (Table 3).

We also noticed statistically significant positive correlation between cumulative smoking (duration of smoking in years) and the number of $\mathrm{MNi}(\mathrm{r}=$ 0.5074; $\mathrm{p}<0.001)$ and NBUDs in the cells $(\mathrm{r}=$ 0.6999; $\mathrm{p}<0.001)$, PYK $(\mathrm{r}=0.4818 ; \mathrm{p}=0.007)$, KYL $(r=0.6592 ; \mathrm{p}<0.001)$ and KHC cells $(\mathrm{r}=$ $0.7702 ; \mathrm{p}<0.001)$. Similarly, smoking intensity (number of consumed cigarettes per day) had an effect on statistically significant increased number 
of nuclear alterations, PYK $(\mathrm{r}=0.5198 ; \mathrm{p}=0.003)$, KYL $(\mathrm{r}=0.4430 ; \mathrm{p}=0.014)$ and KHC cells $(\mathrm{r}=$ $0.5265 ; \mathrm{p}=0.003)$.

\section{DISCUSSION}

BMCyt assay is useful as a biomarker of genetic damage caused by genotoxic and lifestyle factors, environmental and occupational exposures, dietary deficiencies, medical procedures, different diseases, as well as inherited genetic defects in DNA repair. The sex, age, smoking and alcohol consumption can affect MN frequency in buccal cells.

In this study, the baseline frequency of micronuclei was determined in exfoliated cells of the human buccal mucosa of 120 healthy subjects. The sex, age and smoking habits were taken into account. We found the baseline MN frequency in human buccal cells was $0.135 \%$ or $1.35 \%$ in examined sample, which is in agreement with the other published reports: $0.16 \%$ (1), 0.1 to $0.3 \%$ (17) and $0.5-2.5$ MNi per 1,000 cells (3). Micronuclei are regarded as biomarkers of abnormal mitoses involving chromosomal breakage or mis-segregated chromatin. We demonstrated that sex influences the number of $\mathrm{MNi}$ in buccal cells. The number of $\mathrm{MNi}$ was significantly higher in females as compared with males. The ratio between females and males was 1.45 . Also, there was association between the age of the participants and frequency of $\mathrm{MNi}, \mathrm{NBUDs}, \mathrm{KYL}$ and KHC cells. The number of these cytogenetic markers statistically increased with ageing. Concerning sex, the other studies also reported that biomarker frequencies were higher in females than in males by a factor of 1.2 - 1.6, depending on the age group (17-19). However, other authors have shown the spontaneous buccal cell MN frequencies in males and females did not substantially differ, with a slight but not significant excess in males (20). Some studies did not find any association between sex and micronucleus occurrence $(6,21)$, although this association has been reported by others (22-24).

Some authors did not find association between age and micronucleus occurrence $(6,21)$. However, other authors were able to establish a statistically significant effect by age $(8,25-27)$. Results of the study of Piyathilake et al (4) indicated that age and sex were important variables affecting micronucleus frequen- cy. It has been shown that in vivo ageing leads to an increased micronucleus frequency in lymphocytes. Loss of the $\mathrm{X}$ chromosome in females and males and loss of the $\mathrm{Y}$ chromosome in males are among the primary mechanisms explaining this increase (14).

The higher incidence of $\mathrm{MN}$ in both sexes is more manifested in older age groups and the effect of sex becomes more pronounced as age increases. Cytogenetically, ageing is associated with a number of cellular changes, including altered size and morphology, genomic instability and changes in expression and proliferation $(28,29)$. It has been shown that a higher $\mathrm{MN}$ frequency is directly associated with decreased efficiency of DNA repair and increased genomic instability $(30,31)$.

In our study, males had a slightly higher number of cells with NBUD and the number of degenerative nuclear alterations indicative of apoptosis (PYK and KYL cells and KHC cells) than females. However, significantly positive correlations were observed between micronuclei frequencies in human buccal cells and the formation of cells with NBUD, KYL and KHC cells. The PYK, condensed chromatin and KYL are normal correlates of epithelial cell differentiation and maturation. However, they occur at elevated levels in response to cellular injury. The PYK, KHC and condensed chromatin are associated with both cytotoxicity (necrosis and keratinization) and genotoxicity (apoptosis), but KYL is associated with cytotoxicity only. Apoptosis is the major mechanism of cell death in living tissues. Because it is stimulated both by ionizing radiation and by chemicals that bind to DNA, apoptosis may also act as a surveillance mechanism, eliminating cells with genetic damage. Thus, apoptosis may be an indicator of genotoxic insult. Therefore, the BMCyt offers evaluation of chromosomal instability and gene amplification (NBUDs), cytokinesis arrest due to aneuploidy (binucleated cells), and different cell death events (e.g. KHC and PYK cells). Correlation analyses showed that micronucleus frequencies correlated significantly with karyorrhexis, karyolysis, condensed chromatin and binucleates (7).

The most frequently studied lifestyle parameter is smoking. This study showed that buccal cell $\mathrm{MNi}$ and degenerative nuclear alternations were more frequent among cigarette smokers than non-smokers. 
Also, cigarette smoking (the number of cigarettes smoked per day or years of smoking) significantly increases the frequencies of PYK, KYL and KHC cells and years of smoking also increases the frequencies of $\mathrm{MNi}$ and NBUDs in buccal cells. Concerning the number of cigarettes smoked per day or years of smoking, genetic damage shows that only the subjects who smoked the most had a significant increase in MNi and NBUDs. Statistically significant higher frequency of MNi, PYK, KYL and KHC cells was observed in cells collected from female or male smokers than from non-smokers.

There are different results in the literature about the effects of smoking on induction of $\mathrm{MNi}$ in exfoliated buccal cells. Konopacka (6) reported that the frequency of $\mathrm{MNi}$ of oral epithelial cells was three times higher in smokers than non-smokers. It has been suggested that this association is dependent on the number of cigarettes consumed $(26,27)$. Haveric et al (32) studied the effects of cigarette consumption on micronucleus frequencies in peripheral blood lymphocytes and exfoliated buccal cells of young smokers. They observed significantly higher frequency of apoptotic buccal cells in smokers and the frequency of apoptotic cells in this group was significantly influenced by the age of participants and duration of smoking. Yet other publications report no difference between smokers and non-smokers or men and women (33).

\section{CONCLUSIONS}

The BMCyt assay, based on scoring not only MN frequency but also other genome damage markers, dead or degenerated cells, provides a measure of cytotoxic and genotoxic effects.

Our results suggest that the baseline $\mathrm{MN}$ frequency in human buccal cells of 120 healthy subjects was $0.135 \%$ or $1.35 \%$. Significant positive correlations were observed between $\mathrm{MN}$ frequencies and formation of NBUD, KYL and KHC cells.

We demonstrated that sex influences the number of $\mathrm{MNi}$ in human buccal cells. The number of $\mathrm{MNi}$ in cells was significantly higher in females than in males, regardless of the number of consumed cigarettes per day. There was positive association between the age of the participants and frequency of $\mathrm{MNi}, \mathrm{NBUDs}$, KYL and KHC cells. The ageing statistically increased the number of analysed cytogenetic markers.

Statistically significant higher frequency of $\mathrm{MNi}$, PYK, KYL and KHC cells was observed in cells collected from female or male smokers than from non-smokers. Our findings indicated that cigarette smoking (the number of consumed cigarettes per day or years of smoking) significantly increases the frequencies of PYK, KYL and KHC cells. Cytogenetic damages show that subjects who smoked more years had a significant increase in MNi and NBUDs in buccal cells.

\section{COMPETING INTERESTS}

The authors declare no conflict of interest.

\section{ACKNOWLEDGEMENTS}

We acknowledge numerous students who have contributed to the research that has led to a better understanding of the mechanisms underlying micronucleus formation.

\section{REFERENCES}

1. Tolbert PE, Shy CM, Allen JW. Micronuclei and Other Nuclear Anomalies in Buccal Smears: A Field Test in Snuff Users. American Journal of Epidemiology 1991; 134(8)840-850.

2. Fenech M, Holland N, Zeiger E, Chang WP, Burgaz S, Thomas P, et al. The HUMN and $\mathrm{HUMN}_{\mathrm{XL}}$ international collaboration projects on human micronucleus assays in lymphocytes and buccal cells-past, present and future. Mutagenesis 2011; 26(1):239-245.

3. Holland N, Bolognesi C, Kirsch-Volders M, Bonassi S, Zeiger E, Knasmueller $\mathrm{S}$. The micronucleus assay in human buccal cells as a tool for biomonitoring DNA damage: the HUMN project perspective on current status and knowledge gaps. Mutat Res 2008; 659:93-108.

4. Piyathilake CJ, Macaluso M, Hine RJ, Vinter DW, Richards E, Krumdieck CL. Cigarette smoking, intracellular vitamin deficiency and occurrence of micronuclei in epithelial cells of the buccal mucosa. Cancer Epidemiol Biomarkers Prev 1995; 4:751-758.

5. Benites $\mathrm{Cl}$, Amado LL, Vianna RA, Martino-Roth Mda G. Micronucleus test on gas station attendants. Genet Mol Res 2006; 5:45-54.

6. Konopacka M. Effect of smoking and aging on micronucleus frequencies in human exfoliated buccal cells. Neoplasma 2003; 50:380-382.

7. Nersesyan A, Kundi M, Atefie K, Schulte-Hermann R, Knasmüller S. Effect of Staining Procedures on the Results of Micronucleus Assays with Exfoliated Oral Mucosa Cells. Cancer Epidemiol Biomarkers Prev 2006; 15(10):1835-1840.

8. Ozkul Y, Donmez H, Erenmemisoglu A, Demirtas H, Imamoglu N. Induction of micronuclei by smokeless tobacco on buccal mucosa cells of habitual users. Mutagenesis 1997; 12:285-7.

9. Ramirez A, Saldanha PH. Micronucleus investigation of alcoholic patients with oral carcinomas. Genet Mol Res 2002; 1:246-60.

10. Bohrer PL, Filho MS, Paiva RL, da Silva IL, Rados PV. Assessment of micronucleus frequency in normal oral mucosa of patients exposed to car- 
cinogens. Acta Cytol 2005; 49:265-72.

11. Bolognesi C, Nucci MC, Colacci AM, Grilli S, Ippoliti F, Mucci N, et al. Biomonitoring of nurses occupationally exposed to antineoplastic drugs: the IMEPA Project. Epidemiol Prev. 2005; 29:91-5.

12. Çelik A, Çavaş T, Ergene-Gözükara S. Cytogenetic biomonitoring in petrol station attendants: micronucleus test in exfoliated buccal cells. Mutagenesis 2003; 18(5):417-421.

13. Al-Sabti K, Loyd DC, Edwards A, Stegnar P. A survey of lymphocytes chromosomal damage in Slovenian workers exposed to occupational clastogen. Mutat Res 1992; 280:215-223.

14. Nefic H, Handzic I. The effect of age, sex, and lifestyle factors on micronucleus frequency in peripheral blood lymphocytes of the Bosnian population. Mutat Res 2013; 753:1-11.

15. Sarto F, Tomanin R, Giacomelli L, Canova A, Raimondi F, Ghiotto C, et al. Evaluation of chromosomal aberrations in lymphocytes and micronuclei in lymphocytes, oral mucosa and hair root cells of patients under antiblastic therapy. Mutat Res 1990; 228:157-169.

16. Thomas P, Holland N, Bolognesi C, Kirsch-Volders M, Bonassi S, Zeiger E, et al. Buccal micronucleus cytome assay. Nat Protoc 2009; 4:825-837.

17. Fenech M, Holland N, Chang WP, Zeiger E, Bonassi S. The HUman MicroNucleus project-an international collaborative study on the use of the micronucleus technique for measuring DNA damage in humans. Mutat Res 1999; 428:271-283.

18. Fenech M, Bonassi S, Turner J, Lando C, Ceppi M, Chang WP, et al. Intraand inter-laboratory variation in the scoring of micronuclei and nucleoplasmic bridges in binucleated human lymphocytes. Results of an international slide-scoring exercise by the HUMN project. Mutat Res 2003; 534:45-64.

19. Wojda A, Zietkiewicz E, Witt M. Effects of age and gender on micronucleus and chromosome nondisjunction frequencies in centenarians and younger subjects. Mutagenesis 2007; 22(3):195-200.

20. Bonassi S, Coskun E, Ceppi M, Lando C, Bolognesi C, Burgaz S, et al. The HUman MicroNucleus project on eXfoLiated buccal cells $\left(H_{U M N}\right)$ : The role of life-style, host factors, occupational exposures, health status, and assay protocol. Mutat Res 2011; 728(3):88-97.

21. Dórea LTM, Meireles JRC, Lessa JPR, Oliveira MC, de Bragança Pereira CA, de Campos AP, et al. Chromosomal Damage and Apoptosis in Exfoliated Buccal Cells from Individuals with Oral Cancer. International Journal of Dentistry 2012; 2012:1-6.

22. Zakeri F, Assaei RG. Cytogenetic monitoring of personnel working in angiocardiography laboratories in Iran hospitals. Mutat Res 2004; $562(1-2): 1-9$.

23. Gonsebatt ME, Vega L, Salazar AM, Montero R, Guzman P, Blas J. Cytogenetic effects in human exposure to arsenic. Mutat Res 1997; 386:219-228.

24. Pastor S, Gutierrez S, Creus A, Cebulska-Wasilewska A, Marcos R, Micronuclei in peripheral blood lymphocytes and buccal epithelial cells of Polish farmers exposed to pesticides. Mutat Res 2001; 495:147-156

25. Pinto D, Ceballos JM, Garcia G, Guzman P, Del Razo LM, Vera E, et al. Increased cytogenetic damage in outdoor painters, Mutat Res 2000; 467:105-111

26. Wu PA, Loh CH, Hsieh LL, Liu TY, Chen CJ, Liou SH. Clastogenic effect for cigarette smoking but not areca quid chewing as measured by micronuclei in exfoliated buccal mucosal cells. Mutat Res 2004; 562(1-2):27-38.

27. Bloching M, Reich W, Schubert J, Grummt T, Sandner A. Micronucleus rate of buccal mucosal epithelial cells in relation to oral hygiene and dental factors. Oral Oncology 2008; 44(3):220-226.

28. Bolognesi C, Lando C, Forni A, Landini E, Scarpato R, Migliori L, et al. Chromosomal damage and ageing: effect of micronuclei frequency in peripheral blood lymphocytes. Age Ageing 1999; 28:393-397.

29. Zietkiewicz E, Wojda A, Witt M. Cytogenetic perspective of ageing and longevity in men and women. J Appl Genet 2009; 50:261-273.

30. Orsière T, Sari-Minodier I, larmarcovai G, Botta A, Genotoxic risk assessment of pathology and anatomy laboratory workers exposed to formaldehyde by use of personal air sampling and analysis of DNA damage in peripheral lymphocytes. Mutat Res 2006; 605:30-41.

31. Kirsch-Volders M, Mateuca R, Roelants M, Tremp A, Zeiger E, Bonassi S et al. The effects of GSTM1 and GSTT1 polymorphisms on micronucleus frequencies in human lymphocytes in vivo. Cancer Epidemiol Biomarkers Prev 2006; 15(5):1038-1042.

32. Haveric A, Haveric S, Ibrulj S. Micronuclei frequencies in peripheral blood and buccal exfoliated cells of young smokers and non-smokers. Toxicol Mech Methods 2010; 20(5):260-266.

33. Yildirim IH, Yesilada $E$, Yologlu S. Micronucleus frequency in periphera blood lymphocytes and exfoliated buccal cells of untreated cancer patients. Genetika 2006; 42:705-710. 